\title{
Chemical and Morphological Expression of the $B$ and Asp Seedcoat Genes in Phaseolus vulgaris
}

\author{
Clifford W. Beninger ${ }^{1}$ and George L. Hosfield ${ }^{2}$ \\ U.S. Department of Agriculture, Agricultural Research Service, Sugarbeet and Bean Research, Department \\ of Crop and Soil Sciences, Michigan State University, East Lansing, MI 48824
}

Mark J. Bassett ${ }^{3}$

Institute of Food and Agricultural Sciences, Department of Horticultural Sciences, University of Florida, Gainesville, FL 32611-0690

\author{
Shirley Owens ${ }^{4}$ \\ Department of Crop and Soil Sciences, Michigan State University, East Lansing, MI 48824
}

AdDITIONAL INDEX WORDS. common bean, flavonoids, anthocyanins, regulatory genes, phytoalexin, phaseollin

\begin{abstract}
Three common bean (Phaseolus vulgaris L.) seedcoat color (or glossiness) genotypes, differing from each other by a single substitution at a seedcoat locus, were analyzed for presence and concentration of three anthocyanins: delphinidin 3-O-glucoside, petunidin 3-O-glucoside, and malvidin 3-O-glucoside. The three anthocyanins were present in Florida common bean breeding line 5-593 (P C J G B V Asp), matte black (PC J G B V asp), and dark brown violet (P $C J G b V A s p)$, but the amounts varied greatly depending on the genotype. Dark brown violet had $19 \%$ of the total anthocyanin content when compared to 5-593, whereas matte black had amounts intermediate between the two other genotypes. The $B$ gene acts to regulate the production of precursors of anthocyanins in the seedcoat color pathway above the level of dihydrokaempferol formation, perhaps at the chalcone synthase or chalcone isomerase steps in the biosynthetic pathway. We hypothesize that $B$ regulates simultaneously the flavonoid (color) and isoflavonoid (resistance) pathways. The $I$ gene for resistance to bean common mosaic virus (BCMV) is known to be linked closely to $B$. It is therefore hypothesized that the $I$ gene function may be to respond to BCMV infection by dramatically increasing (over a low constituitive level) production in the 5-dehydroxy isoflavonoid pathway, which leads to synthesis of the major phytoalexin, phaseollin, for resistance to BCMV. Alternatively, the $B$ and $I$ genes may be allelic. The Asp gene affects seedcoat glossiness by means of a structural change to the seedcoat. We demonstrate that $A s p$ in the recessive condition (asp/asp) changes the size and shape of the palisade cells of the seedcoat epidermis, making them significantly smaller than either 5-593 or dark brown violet. Asp, therefore, limits the amounts of anthocyanins in the seedcoat by reducing the size of palisade cells.
\end{abstract}

The genetics of common bean (Phaseolus vulgaris) seedcoat color, including the very complex interactions of the eight principal genes involved in color determination, was reviewed and summarized by Prakken (1970, 1972). In brief, the "ground factor" gene $P$ is needed to avoid white seedcoats (with $p$ ) or gray white (with $p^{\text {gri }}$ ); and the color genes $C$ and $J$ are needed to fully express the color modifying genes $G$ (yellow brown), $B$ (greenish brown), $V$ (violet to black), and $R k$ (recessive red from red kidney). The dominant red color gene $R$ is very closely linked to $C$, and the bracket convention, $[C r]$, is used to indicate this virtually unbreakable linkage (Bassett, 1991). The function of the seedcoat color gene $B$ was first discovered by Kooiman (1920), but the gene symbol, $B$, was first assigned to the locus by Lamprecht (1932) and accepted by Prakken (1970) in his gene symbol reconciliation.

Received for publication 29 June 1999. Accepted for publication 11 Oct. 1999 Names are necessary to report factually on available data; however, the USDA neither guarantees nor warrants the standard of the product, and the use of the name by the U.S. Dept. Agr. (USDA) implies no approval of the product to the exclusion of others that may be suitable. We thank the Laser Scanning Microscope Laboratory and Center for Electron Optics at Michigan State University for use of the microscope facilities. The cost of publishing this paper was defrayed in part by the payment of page charges. Under postal regulations, this paper therefore must be hereby marked advertisement solely to indicate this fact.

${ }^{1}$ Postdoctoral research associate.

${ }^{2}$ Research geneticist, to whom reprint requests should be addressed. ${ }^{3}$ Professor.

${ }^{4}$ Research microscopist.
The $I$ gene resistance to bean common mosaic virus (BCMV) was first discovered by Corbett in 1931 as a spontaneous mutant in 'Stringless Green Refugee' (Pierce, 1934). Investigation of the inheritance of the resistance and assignment of the gene symbol, $I$, was conducted by Ali (1950). The $B$ and $I$ loci are closely linked (cM $<0.25$, as calculated by present authors), and no crossovers were observed (Park and Tu, 1986; Temple and Morales, 1986). The $I$ gene has broad spectrum resistance to legume potyviruses (BCMV, blackeye cowpea mosaic virus, cowpea aphid-borne mosaic virus, soybean mosaic virus, and watermelon mosaic virus-2), and no crossovers were observed (within $<2 \mathrm{cM}$ est. total distance) between any of five potyvirus resistances and the $B$ gene (Kyle and Dickson, 1988). The $B-I$ region is known to be telomeric in linkage group D (E. Vallejos, unpublished data), and a randomly amplified polymorphic DNA (RAPD) marker has been developed for I (Haley et al., 1994).

The Asp gene is not a seedcoat color gene, but controls the glossiness, or shine, of the seedcoat. Until recently, study of the function of Asp has been largely ignored since its genetic characterization by Lamprecht (1940). Bassett (1996) has clarified the roles of Asp and $J$ in producing dull seedcoats and other effects. The $a s p$ allele produces a duller seedcoat than $j$, and $a s p$ is much more frequently present than $j$ in widely grown cultivars. Dull seedcoat is the only visible effect of asp, whereas the primary effect of $j$ is to produce paler, immature seedcoat colors in whatever genetic background it occurs (Bassett, 1996).

In his pioneering work, Feenstra (1960) isolated and identified a number of compounds from various seedcoat color genotypes. 
However, his genetic stocks all had the $B$ allele in the recessive condition, and he, therefore, could not attempt to identify the compounds associated with dominant $B$. One proposed function of the $B$ locus is hydroxylation of the B-ring of the flavonoid or anthocyanin nucleus (Leakey, 1988). However, no experimental evidence has been presented to date to support this hypothesis.

One of the authors (M.J. Bassett) developed genotypes with different seedcoat colors in a common genetic background (Florida breeding line 5-593) to facilitate investigation of the chemistry of seedcoat pigments by phytochemical extraction and analysis. Determination of the seedcoat genotype of 'Prim' (a Manteca class bean; bred by C. S. Leakey) by Bassett (1999) has led to determination of the flavonoid compounds produced by the genotype $P[C r] d j G b v^{\text {lae }}$ (Beninger et al., 1998). Subsequently, determination of the flavonoid compounds was achieved in 1) three seedcoat genetic stocks of Bassett- $G B v \mathrm{BC}_{3}$ 5-593, $G b$ $v \mathrm{BC}_{3}$ 5-593, and $g b v \mathrm{BC}_{3}$ 5-593 (Beninger et al., 1999) and 2) in 'Montcalm' (Beninger and Hosfield, 1999), a dark red kidney cultivar with genotype $P c^{\mathrm{u}} J g B v r k^{\mathrm{d}}$ (Bassett, 1998a).

The three main anthocyanins associated with black beans (with seedcoat $P C J B V$ ) have been isolated and identified previously by Takeoka et al. (1997). This work provides a basis for contrasting the base line anthocyanins of genotype $P C J B V$ with the effects of single recessive gene substitutions into the black seedcoat genotype. The purposes of the present paper were to 1) identify the kind and amount of anthocyanins found in a seedcoat genotype with the $b$ substitution in the black seedcoat genotype, as an approach to defining the function of the $B$ gene and 2) determine the structural effect of the asp substitution in the black seedcoat genotype by means of scanning electron micrographs of surfaces and cross sections of the seedcoat.

\section{Materials and Methods}

Plant material. The three genetic stocks used for this investigation were developed by M.J. Bassett (1998a, 1998b, 1998c). Line 5-593 has the Asp gene for shiny seedcoat and dominant genes for seedcoat color at seven seedcoat color loci $(\mathrm{P}[\mathrm{Cr}] \mathrm{JG}$ $B V R k$ ), except for the dominant red locus $R$, which is tightly linked to the $C$ locus (Bassett, 1998a; Prakken, 1970). The other two genetic stocks were $G b V_{B_{3}} 5-593$ with dark-brown violet seedcoats and asp $\mathrm{BC}_{3}$ 5-593 with matte (dull) black seedcoats. Using 5-593 as a standard genotype, dark brown violet differs only by the $b$ substitution and matte black differs only by the $a s p$ substitution. The two genetic stocks in $\mathrm{BC}_{3}$ to 5-593 are near isogenic with respect to the recurrent parent 5-593, but an isogenic condition is not needed for our experimental purpose (Beninger et al., 1999).

The genotypes used were increased during summer 1996 in a nursery at the Saginaw Valley Bean and Sugarbeet Research Farm, Saginaw, Mich. The soil type on the farm is a Mistequay silty clay [fine, illitic (calcareous), frigid typic Haplaquolls]. After harvesting in autumn, seeds were frozen at $-20^{\circ} \mathrm{C}$.

SeEdcoat PReparation. A total of $10 \times 100,7 \times 100$, and 13 $\times 100 \mathrm{~g}$ fresh weight $(\mathrm{FW})$ allotments of 5-593, matte-black, and dark-brown-violet beans were soaked in distilled water for 1 to 3 $\mathrm{h}$ to facilitate separation of seedcoats from the cotyledons. Water exudates were saved, frozen with seedcoats at $-80{ }^{\circ} \mathrm{C}$ and then placed in a freeze drier (Genesis 12 EL; Virtis, Gardiner, N.Y.). After freeze drying, seedcoats were ground to a fine powder in a coffee grinder, packed into a glass column $(5.0 \times 30.0 \mathrm{~cm})$ and extracted sequentially with hexane, ethyl acetate, and acidified methanol (10\% formic acid). All extracts were dried under reduced pressure in a rotary evaporator (Buchi Labortechnik AG, Flawil, Switzerland), placed in vials and stored at $-20^{\circ} \mathrm{C}$ before separation using a high performance low pressure liquid chromatography (HPLPLC) system.

HPLPLC SYSTEM. A Michel-Miller column $(50 \times 600 \mathrm{~mm}$, Ace glass Co., Louisville, Ky.) was packed evenly with $650 \mathrm{~g}$ of C18 $(30 \mu \mathrm{M})$ (Hyperprep; Supelco, Bellefonte, Pa.) as the stationary phase and $100 \%$ methanol as the mobile phase. A precolumn (22 $\times 130 \mathrm{~mm}$ ) packed to $50 \%$ of its volume with C18 was placed between the pump and main column. All column end fittings were assorted Ace-Thred matches and filter discs were used to retain the column packing material. The precolumn and main column were connected to a HPLC pump (model 510; Waters, Milford, Mass.), which had been modified by installing high flow-through heads $\left(25 \mathrm{~mL} \cdot \mathrm{min}^{-1}\right.$ maximum flow rate). A pressure relief valve set to the manufacturer's (Alltech Inc., Deerfield, Ill.) tolerance of the column (200 psi maximum) was placed between the pump and precolumn. The column was connected to a UV-vis detector (model 486; Waters) set at a detection wavelength of $520 \mathrm{~nm}$ to monitor anthocyanin bands as they eluted.

The column was equilibrated isocratically with 10 formic acid : 65 water : 25 methanol for $24 \mathrm{~h}$ before sample loading. A sample of $929.0 \mathrm{mg}$ of 5-593 dried methanol extract was dissolved in 3 $\mathrm{mL}$ of the same solvent used for column equilibration and loaded directly onto the C18 of the precolumn. After the sample had adsorbed onto the $\mathrm{C} 18$, the precolumn was filled with solvent and connected to the pump with a flow rate set at $1.5 \mathrm{~mL} \cdot \mathrm{min}^{-1}$. Fractions containing anthocyanins were then collected as they eluted from the main column.

Semipreparative HPLC. To purify peaks further for nuclear magnetic resonance (NMR) analysis, the three collected fractions were repeatedly injected on a reverse-phase semipreparative C18 column $(10 \times 250 \mathrm{~mm}, 5 \mu \mathrm{m})$ (Capcell Pak; Shiseido, Tokyo, Japan) connected to a multisolvent pump, photodiode array (PDA) detector, and autosampler (models 600, 996, and 717, respectively; Waters). The flow rate was $2.0 \mathrm{~mL} \cdot \mathrm{min}^{-1}$, and the solvent system was the same as that used on the HPLPLC column with a detection wavelength of $520 \mathrm{~nm}$ and run time of $16 \mathrm{~min}$. All of fraction $3(18.6 \mathrm{mg})$ and $20 \mathrm{mg}$ of fraction 1 and 2 were dissolved in $2 \mathrm{~mL}$ of 10 formic acid : 65 water : 25 methanol and filtered through a $2-\mu \mathrm{m}$ filter into HPLC injection vials. For each sample a total of twenty $100 \mu \mathrm{L}$ injections were made and the main peaks collected with an automatic fraction collector (Waters). Injection, separation, and collection of the fraction were fully automated. With short run times (16 min), final purification of each anthocyanin was achieved in at most 6 to $7 \mathrm{~h}$.

High-PRESSURE ANALYTICAL LIQUid CHROMATOGRAPHY. The standards delphinidin 3-O-glucoside, petunidin 3-O-glucoside, and malvidin 3-O-glucoside, obtained from Florida common bean breeding line 5-593, were coinjected in the above order with crude methanol extracts of matte black and dark brown violet. Each corresponding peak area in the methanol extracts was increased, indicating the presence of the same compounds in matte black and dark brown violet. To determine the concentration of the three anthocyanins in 5-593, matte black, and dark brown violet bean seedcoats, a total of nine seeds (which had been stored at $-20{ }^{\circ} \mathrm{C}$ ) for each genotype were divided into three lots. Each lot was weighed, seedcoats were removed, and these were then placed in mortars. Five to $6 \mathrm{~mL}$ of extraction solvent $(10$ formic acid : 40 water : 50 methanol) was added along with a small amount of celite to act as an abrasive. Tissue was ground with a 
pestle for $\approx 1 \mathrm{~h}$, the extract placed into microcentrifuge tubes and centrifuged for $10 \mathrm{~min}$ at $10,000 \mathrm{gn}$. The supernatant was evaporated to dryness under reduced pressure in a rotary evaporator, resuspended in $1 \mathrm{~mL}$ extraction solvent, and filtered through 0.2 $\mu \mathrm{m}$ filters (Whatman Inc.) into HPLC vials for analysis. Anthocyanin standards which had been purified and identified from 5593 were made up to $1.0 \mathrm{mg} \cdot \mathrm{mL}^{-1}$ and then serially diluted to give $0.5,0.25,0.125$, and $0.0625 \mathrm{mg} \cdot \mathrm{mL}^{-1}$ and injected immediately before the crude seedcoat extracts. Calibration curves were then calculated using Millenium 32 software (Waters): delphinidin 3$O$-glucoside $r^{2}=0.999$, petunidin 3-O-glucoside $r^{2}=0.998$, and malvidin 3-O-glucoside $r^{2}=0.997$. Concentrations of these compounds were calculated from the seedcoat crude extract injections and expressed as mg/100 $\mathrm{g} \mathrm{FW}$ of whole bean. Differences in amounts of anthocyanins between genotypes were analyzed using the SAS (1989) GLM procedure with a StudentNewman-Keuls comparison of means.

NMr EXPERIments. Purified anthocyanins from the semipreparative HPLC column were dissolved in $\mathrm{CD}_{3} \mathrm{OD}$ (deuterated methanol) into which a drop of $20 \% \mathrm{DCl}$ (deuterated chloride) in $\mathrm{D}_{2} \mathrm{O}$ (deuterated water) was added. Proton $\left({ }^{1} \mathrm{HNMR}\right)$ spectra were obtained using a $500 \mathrm{MHz}$ NMR (VXR; Oxford Instruments, Eynsham, Osfordshire, U.K.) with Varian software (Varian Assoc., Palo Alto, Calif.) at the Max T. Rogers NMR facility in the Department of Chemistry, Michigan State University.

Electron Microscopy. Six beans from each of the three bean genotypes were randomly selected. Samples prepared for scanning electron microscopy were air-dried, dissected or sectioned with a razor blade, mounted on aluminum stubs, sputter coated with gold and observed using a JEOL JSM-6400 scanning electron microscope (Japan Electron Optics Laboratories, Tokyo, Japan) at $12 \mathrm{kV}$ of accelerating voltage. For measurements of cell length, three beans were sampled randomly from each genotype and sectioned at approximately the same part of the bean (transverse section through center of bean, and length measurements taken from cells on the surface opposite to the hypocotyl). Five measurements were taken from the base of the palisade cell to the top of the cell for each bean. Data were analyzed using SAS (1989) GLM procedure with Student-Newman-Keuls comparison of means.

\section{Results and Discussion}

Crude extract from the 5-593 line showed an HPLC profile with retention times of the three anthocyanins almost identical to the chromatogram presented by Takeoka et al. (1997). However, we found small amounts of a fourth unidentified anthocyanin (Fig. 1). The three compounds were obtained at a purity of $84 \%$ 94\% from the HPLPLC column, and the UV-vis absorption spectra of the three compounds were similar to the anthocyanins characterized by Takeoka et al. (1997) (Table 1). Recovery of the compounds was $123.8,26.5$, and $18.4 \mathrm{mg}$ from $929.0 \mathrm{mg}$ of crude methanol extract for delphinidin 3-O-glucoside, petunidin 3-O-

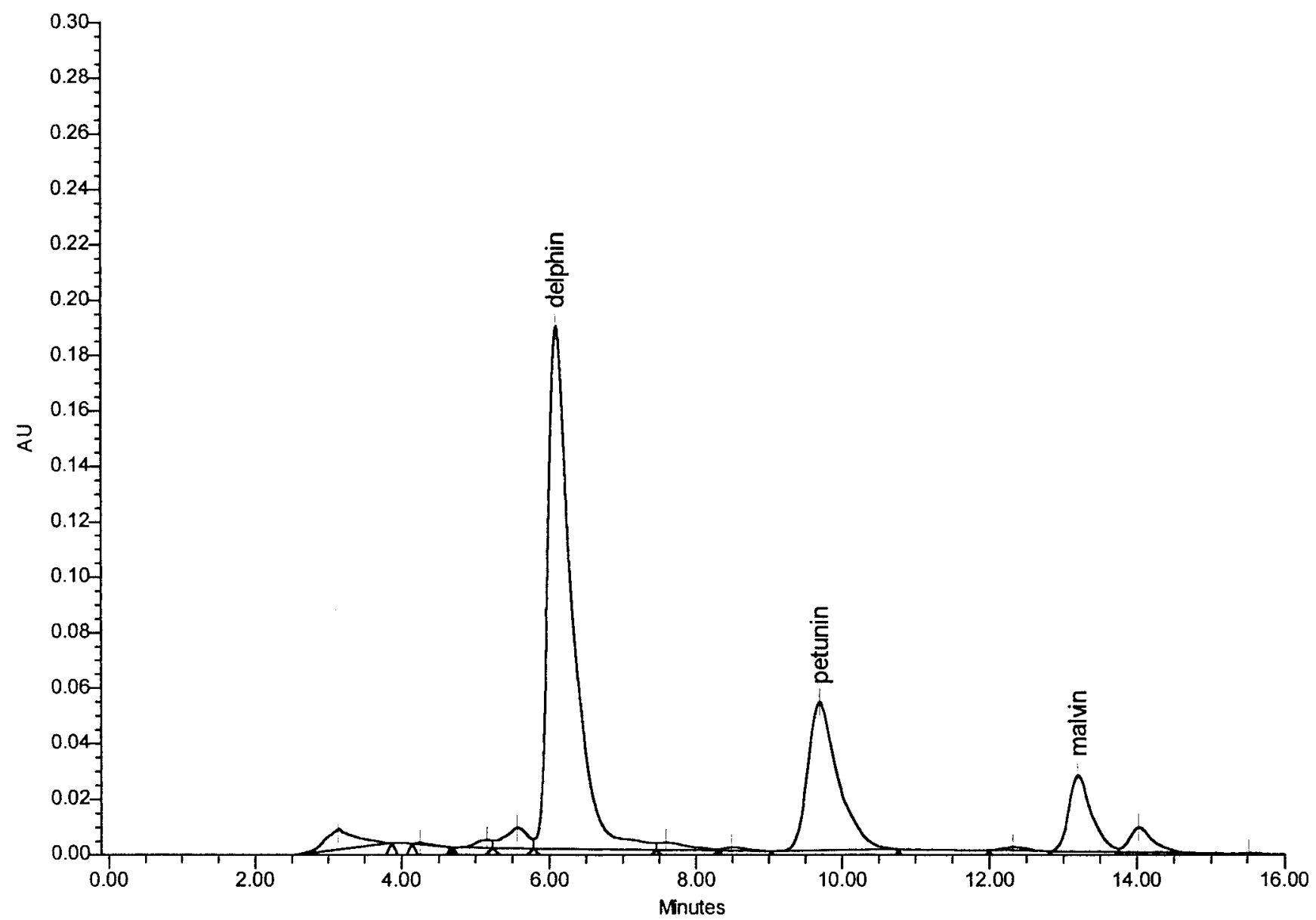

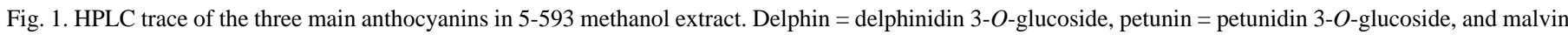
$=$ malvidin $3-O$-glucoside. 


\begin{tabular}{lccc} 
Fraction & $\mathrm{A}_{\max }^{\mathrm{z}}$ & $\mathrm{A}_{440} / \mathrm{A}_{\max } \%^{\mathrm{y}}$ & absorbance for fraction \\
\hline 1 & 524.8 & 25.8 & 93.45 \\
2 & 527.3 & 26.2 & 83.86 \\
3 & 528.5 & 26.1 & 88.25
\end{tabular}

${ }^{\mathrm{z}}$ Band I maximum absorbance as measured by photodiode array scan, $\lambda=200-600 \mathrm{~nm}$.

${ }^{y}$ Ratio of absorbance at $\lambda=440 \mathrm{~nm}$ to maximum absorbance as measured by photodiode array scan, $\lambda=200-600 \mathrm{~nm}$.

xAbsorbance of the main peak is measured at the maximum absorbance for each anthocyanin and divided the total of smaller peak absorbances (impurities) in the wavelength range of $510-530 \mathrm{~nm}$. This gives an indication of the purity of the collected fraction.

glucoside, and malvidin 3-O-glucoside, respectively. After further purification of these fractions using semipreparative HPLC, pure compounds were subjected to ${ }^{1} \mathrm{HNMR}$ analysis; the ${ }^{1} \mathrm{HNMR}$ spectra agreed with Takeoka et al. (1997):

Delphinidin 3-O-glucoside (1); ${ }^{1} \mathrm{HNMR} 8.99$ [1H, s, H-4], 7.79 [2H, s, H-2'6'], 6.89 [1H, s, H-8], 6.67 [1H, s, H-6], $5.30[1 \mathrm{H}$, $\mathrm{d}, J=7.65$, glucose $\mathrm{H}-1 "]$.

Petunidin 3-O-glucoside (2); ${ }^{1} \mathrm{HNMR} 8.98$ [1H, s, H-4], 7.96 [1H, s, H-6'], 7.76 [1H, s, H-2'], 6.89 [1H, s, H-8], 6.62 [1H, s, H6], 5.30 [1H, d, $J=7.73$, glucose $\mathrm{H}-1 "], 3.95$ [3H, s, $\left.\mathrm{OCH}_{3}-3^{\prime}\right]$.

Malvidin 3-O-glucoside (3); ${ }^{1} \mathrm{HNMR} 9.0$ [1H, s, H-4], 8.08 [2H, s, H-2'6'], 6.98 [1H, s, H-8], 6.67 [1H, s, H-6], 5.35 [1H, d, $J=7.51$, glucose $\mathrm{H}-1 "$ "], 3.99 [6H, s, $\left.\left(\mathrm{OCH}_{3}\right)_{2}-3^{\prime} 5^{\prime}\right]$.

Although the same three anthocyanins were present in each genotype (Fig. 2), there appeared to be differences in their concentrations, and, therefore, after isolation and characterization of the anthocyanins, quantitative HPLC was carried out. The dark brown violet line had one fifth the concentration of the main anthocyanin, delphinidin 3-O-glucoside, as line 5-593, and this difference was statistically significant (Table 2). The total amount of the three anthocyanins in the dark brown violet line was only $19 \%$ of the amount found in line 5-593.

With regard to the seedcoat determining loci, the only difference between the dark brown violet line and line 5-593 is a single recessive substitution at the $B$ locus. Since the same compounds were present in both dark brown violet and 5-593, but at reduced concentrations, the $B$ locus does not act in a qualitative manner. The seedcoat color gene $B$, therefore, acts in a quantitative fashion regulating the amounts of the three anthocyanins. This suggests that the $B$ gene acts to regulate a common precursor to all anthocyanins. According to this hypothesis, the dominant allele $B$ produces more (than $b$ ) of the precursor, which is then converted to anthocyanins. In addition, it is known that substitution of $b$ for $B$, changing bean genotype $P C J G B v$ (dark brown seedcoat) to $P C J G b v$ (yellow brown seedcoat), causes a decrease in the amount of the main flavonoid monomer, astragalin (kaempferol 3-O-glucoside) (Beninger et al., 1999). Since dihydrokaempferol is needed for synthesis of both anthocyanins and flavonol glycosides, $B$ may act to promote synthesis of a common precursor, either at or before conversion of the flavanone, naringenin, to dihydrokaempferol in the flavonoid biosynthetic pathway (Fig. 3). Koes et al. (1994) showed that flavonoid biosynthesis is controlled mainly at the level of transcription of structural genes. There is no experimental evidence to date, including the present study, suggesting the $B$ gene is responsible for hydroxylation of the B-ring of the flavonoid nucleus, as speculated by Leakey (1988).

It was not our objective at this time to study the chemistry of the isoflavonoid pathway (Fig. 3). However, due to the tight linkage between the $B$ and $I$ gene and results of the current study, we offer suggestions regarding the function of the $B$ gene to assist future research. The isoflavonoid pathway is induced by infection with bean common mosaic virus (BCMV), and the main isoflavonoid phytoalexin produced is phaseollin (Dewick, 1994; Lamb et al., 1989). Isoflavonoids can be produced from conversion of naringenin by 2-isoflavone synthase (IFS) and 2hydroxyisoflone dehydratase (IFD) to the isoflavonoid genistein (or) through conversion of liquiritigenin by IFS and IFD to daidzein (Heller and Forkman, 1994). Since the main isoflavonoid phytoalexin in $P$. vulgaris lacks a $5-\mathrm{OH}$, and, therefore, liquiritigenin is the substrate for the chalcone isomerase (CHI) enzyme.

HyPOTHESIS OF ALLELISM OF $B$ AND $I$. As we indicate above, our data suggest the $B$ gene could act to regulate the precursor of any compound before dihydrokaempferol in the flavonoid color pathway (Fig. 3), perhaps, even up to the point of regulating production of phenylalanine lyase (PAL). A flower-specific regulator of the PAL gene in Phaseolus vulgaris $(g P A l 2)$ has been identified previously (Sablowski et al., 1994). However, the tight linkage observed between the $B$ and $I$ genes, and the fact that the color and isoflavonoid pathways (Fig. 3) diverge immediately after formation of chalcone, would seem to indicate that both genes act either at the chalcone synthase (CHS) or CHI levels. Therefore, the $B$ and $I$ genes may be synonyms for a single, conserved regulatory gene that controls activity of the structural genes for $\mathrm{CHS}$ or $\mathrm{CHI}$ (Fig. 3). In this case the $B$ gene control of seedcoat color, and the $I$ gene control of phaseollin production, are actually pleiotropic effects of one regulatory gene probably controlling transcription

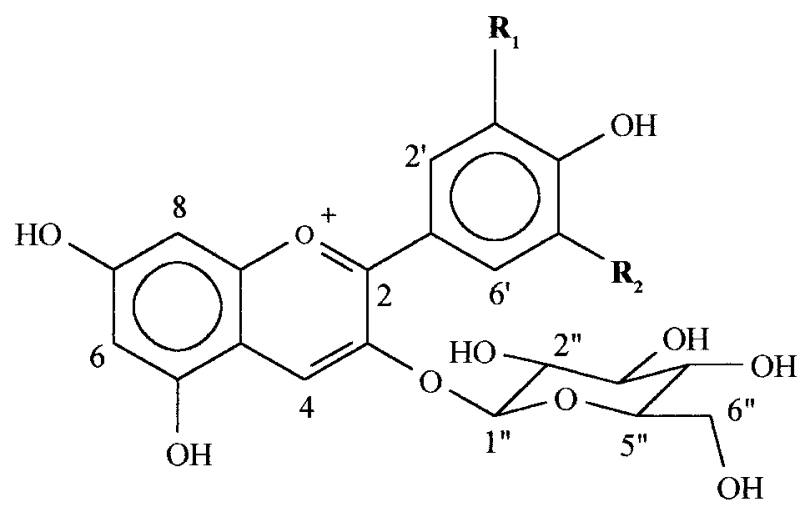

Fig. 2. Structure of the three anthocyanins found in 5-593, matte black, and dark brown violet. $1=$ delphinidin $3-O$-glucoside $\left(\mathrm{R}_{1}=\mathrm{R}_{2}=\mathrm{OH}\right), 2=$ petunin $=$ petunidin 3-O-glucoside $\left(\mathrm{R}_{1}=\mathrm{OCH}_{3} \mathrm{R}_{2}=\mathrm{OH}\right)$, and $3=$ malvidin 3-O-glucoside $\left(\mathrm{R}_{1}=\mathrm{OCH}_{3} \quad \mathrm{R}_{2}=\mathrm{OCH}_{3}\right)$ 
Table 2. Concentrations of the three main anthocyanins and seedcoat thickness of three common bean genotypes.

\begin{tabular}{|c|c|c|c|c|}
\hline \multirow[b]{2}{*}{ Genotype $^{\mathrm{z}}$} & \multicolumn{3}{|c|}{$\begin{array}{l}\text { Anthocyanin concn } \\
(\mathrm{mg} / 100 \mathrm{~g} \text { fresh } \mathrm{wt})\end{array}$} & \multirow[b]{2}{*}{$\begin{array}{c}\text { Palisade cell } \\
\text { size }(\mu \mathrm{M})\end{array}$} \\
\hline & $\begin{array}{l}\text { Delphinidin } \\
\text { glucoside }\end{array}$ & $\begin{array}{l}\text { Petunidin } \\
\text { glucoside }\end{array}$ & $\begin{array}{l}\text { Malvidin } \\
\text { glucoside }\end{array}$ & \\
\hline 5-593: PCJGBVAsp & $477.5 \mathrm{a}^{\mathrm{y}} \pm 31.0$ & $69.5 \mathrm{a} \pm 4.2$ & $31.7 \mathrm{a} \pm 4.4$ & $40.8 \mathrm{a} \pm 0.73$ \\
\hline MTB: $P C J G B V$ asp & $261.6 \mathrm{~b} \pm 49.0$ & $40.6 \mathrm{~b} \pm 8.7$ & $17.3 \mathrm{~b} \pm 3.6$ & $32.1 \mathrm{c} \pm 0.66$ \\
\hline DBV: $P C J G \boldsymbol{b} V A s p$ & $100.8 \mathrm{c} \pm 16.4$ & $6.5 \mathrm{c} \pm 1.5$ & $2.4 \mathrm{c} \pm 0.15$ & $35.3 b \pm 0.55$ \\
\hline
\end{tabular}

$\overline{\mathrm{y}} \mathrm{MTB}=$ matte black, DBV = dark brown violet.

${ }^{\mathrm{z}}$ Mean separation within columns by Student-Newman-Keuls test, $P \leq 0.05$.

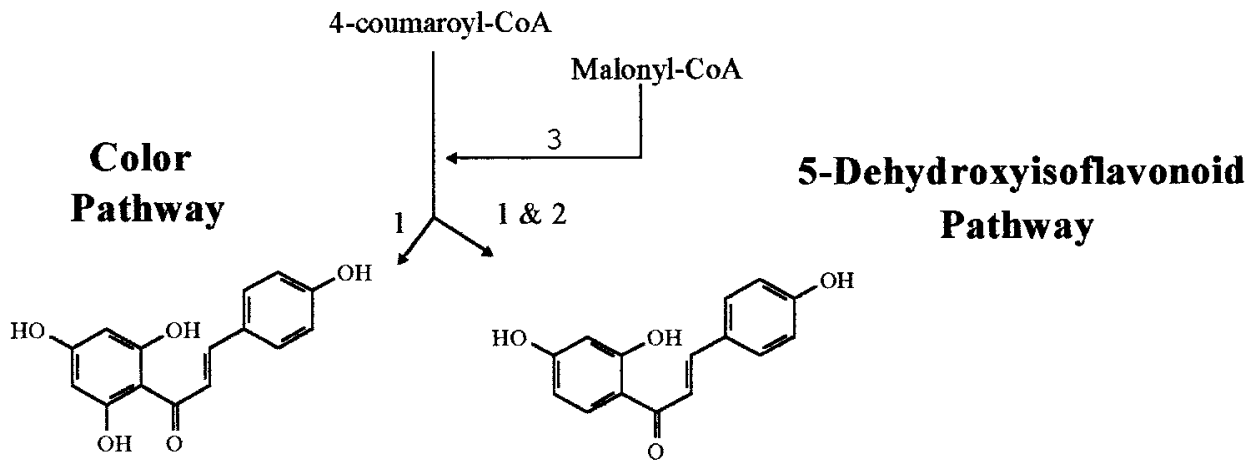

$2^{\prime}, 4^{\prime}, 6^{\prime}, 4-$ Tetrahydroxychalcone

2',6,4-Trihydroxyisoliquiritigenin<smiles>O=C1C[C@H](c2ccc(O)cc2)Oc2cc(O)cc(O)c21</smiles>

4',5,7-Tribydroxyflavanone (Naringenin)<smiles>O=C1c2c(O)cc(O)cc2O[C@@H](c2ccc(Cl)cc2)[C@@H]1O</smiles>

Dihydrokaempferol<smiles>O=c1c(O)c(-c2ccc(O)cc2)oc2cc(O)cc(O)c12</smiles>

Kaempferol<smiles>O=c1c(OC2OC(CO)C(O)COC2O)c(-c2ccc(O)cc2)oc2cc(O)cc(O)c12</smiles>

Flavonol 3-O-glycosides<smiles>O=C1C[C@H](c2ccc(O)cc2)Oc2cc(O)ccc21</smiles>

4',7-Dihydroxyflavanone (Liquiritigenin)<smiles>Oc1ccc([C@H]2Oc3cc(O)cc(O)c3[C@H](O)[C@H]2O)cc1</smiles><smiles></smiles><smiles></smiles>

Pelargonidin<smiles></smiles>

Anthocyanidin 3-O-glucosides of CHI. However, to date, only one CHS (Rommeswinkel et al., 1992) and one CHI protein (Dixon et al., 1988; Mehdy and Lamb, 1987) have been isolated from $P$. vulgaris, which would indicate there is only one copy of the CHS and $\mathrm{CHI}$ structural genes present. If this holds true, then the pleiotripic effects observed cannot be the result of a single regulatory gene acting on different copies of CHS and $\mathrm{CHI}$.

TWO-GENE HYPOTHESIS FOR $B$ AND $I$. The $B$ gene may regulate the transcription of $\mathrm{CHS}$ or $\mathrm{CHI}$, which produce the chalcone or flavanone, respectively, that is a precursor to all other color compounds (Fig. 3). The $B$ gene may also have this same function in the isoflavonoid pathway and act to regulate the $\mathrm{CHS}$ or the CHI structural genes for synthesis of chalcone or conversion of isoliquiritigenin to liquiritigenin, respectively (Fig. 3). Thus, $B$ may be involved in simultaneous regulatory functions in both the seedcoat color and isoflavonoid pathways. One possible function of $I$ in this two-gene model is that it regulates synthesis of polyketide reductase (PKR). This enzyme removes a hydroxyl group from the 5-position of the flavonoid nucleus to form the precursor (isoliquiritigenin) needed for synthesis of the phytoalexin phaseollin and other 5-dehydroxy isoflavonoids. Phaseollin may be produced constitutively in small amounts; however, upon infection with BCMV the $I$ gene may act to dramatically increase synthesis of PKR, and consequently increase levels of 5dehydroxy isoflavonoid precur-

Fig. 3. Flavonoid biosynthetic pathway in $P$. vulgaris (adapted from Heller and Forkman 1994). Enzymes are numbered as $1=$ chalcone synthase (CHS), $2=$ polyketide ruductase (PKR), $3=$ chalcone isomerase (CHI), $4=2$-hydroxyisoflavone synthase (IFS), $5=2$-hydroxyflavone dehydratase (IFD), $6=$ flavanone 3 -hydroxylase (FHT), 7 = dihydroflavonol 4-reductase (DFR), $8=$ anthocyanidin synthase (ANS), $9=$ flavonol synthase (FLS), $10=$ flavonoid 3-O-glucosyl transferase (FGT). 


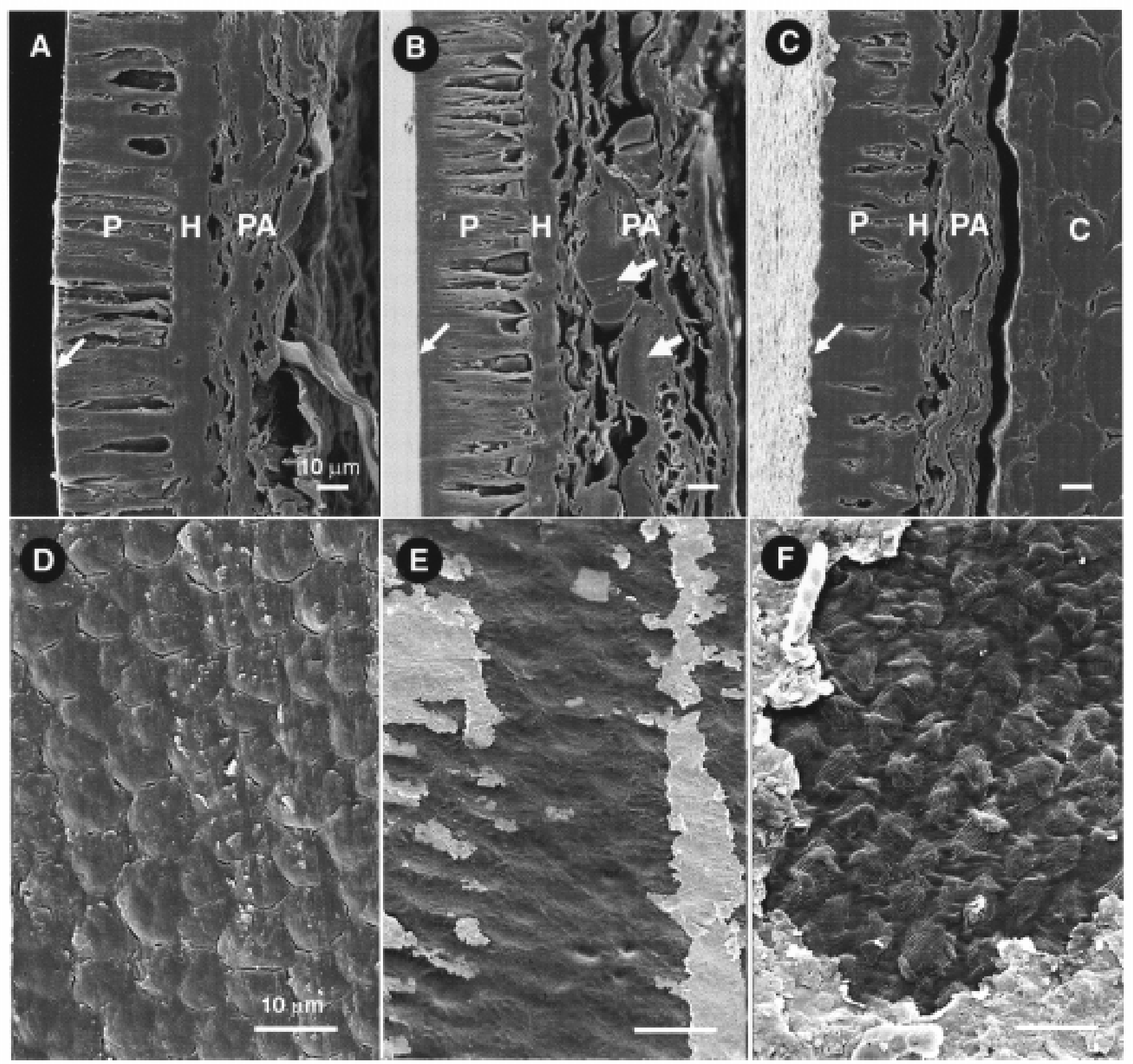

Fig. 4. Scanning electron micrographs of (A) 5-593, (B) dark brown violet, and (C) matte black, in cross section and (D-F) surface scans with most or all of the cuticle removed. $\mathrm{P}=$ palisade layer, $\mathrm{H}=$ hourglass cells, $\mathrm{PA}=$ parenchyma, $\mathrm{C}=$ cotyledon. Small arrows point to surface of the palisade cells. Note the roughness on the ends of cells for matte black and thickness of the entire seedcoat compared to 5-593 and dark brown violet in the cross sections (A-C). Also note the difference in surface roughness of matte black $(\mathbf{F})$ when compared to the other genotypes (D and $\mathbf{E})$. Large arrows in B indicate large parenchyma cells with tannins in the vacuoles.

sors. Thus, the regulatory roles of $B$ and $I$ in the isoflavonoid pathway may be confounded (from the perspective of phaseollin output), i.e., they regulate the same pathway, but at different steps.

DULL SEEDCOAT GENE ASP. The significantly lower concentrations of anthocyanins found in the matte black genotype at first appeared problematic since the Asp gene is known to alter only the physical microstructure of the bean seedcoat (Lamprecht, 1940). Lamprecht (1940) found that when Asp is in the recessive state (asp/asp) the dullness of the seedcoat is caused by elevations at the ends of the palisade cells which form the epidermis. These elevations can be seen clearly in the scanning electron micrographs of the seedcoat cross sections for matte black compared to line 5-593 and dark brown violet (Figs 4A-C). When the cuticle is removed and the surface of the bean is scanned with the electron microscope, the elevations can be seen as rough endcapping of the palisade cells (Fig. 4D-F). The cross sections also showed that the seedcoat of matte black seemed thinner and less pronounced than in either 5-593 or dark brown violet (Fig. 4A-C). Matte black palisade cells were significantly smaller than either dark brown violet or 5-593 when length of cell was used as an indicator of cell size (Table 2). When the asp allele is in the recessive state, it may act not only to produce a rough endcap of the pallisade cells, but reduce the size of the cell, resulting in a thinner seedcoat when compared to 5-593 and dark brown violet. Therefore, the significantly lower amount of anthocyanins in matte black when com- 
pared to 5-593 appears to be caused by a reduction in palisade cell size due to the action of asp/asp.

As discussed above, the $B$ and $I$ genes may regulate both the color and isoflavonoid biosynthetic pathways in $P$. vulgaris. More research is needed to clarify the role of $B$ in the regulation of phaseollin production. Genetic stocks with genotypes $B I, B i$, $b I$, and $b i$ need to be studied to clarify the regulatory roles of $B$ and $I$. This would define their separate roles, assuming the two genes are not allelic. Our data do not appear to suggest any regulatory role for $a s p$ in the production of phaseollin.

\section{Literature Cited}

Ali, M. 1950. Genetics of resistance to the common bean mosaic virus in the bean (Phaseolus vulgaris L.). Phytopathology 40:69-79.

Bassett, M.J. 1991. A revised linkage map of common bean. HortScience 27:834-836.

Bassett, M.J. 1996. The margo (mar) seedcoat color gene is a synonym for the Joker $(j)$ locus in common bean. J. Amer. Soc. Hort. Sci. 121:1028-1031.

Bassett, M.J. 1998a. A test cross protocol for determining the genotype of dark red seedcoat colors in common bean. J. Amer. Soc. Hort. Sci. 123:1048-1052.

Bassett, M.J. 1998b. List of seed coat genetic tester stocks in the 5-593 genetic background. Annu. Rpt. Bean Improvement Coop. 41:125-126.

Bassett, M.J. 1998c. The genotype for seed coat color and pattern of breeding line 5-593, 1998. Annu. Rpt. Bean Improvement Coop. 41:127-128.

Bassett, M.J. 1999. The seedcoat color genotype of 'Prim' and the Manteca and Coscorrón market classes of common bean. HortScience 34:336-337.

Beninger, C.W. and G.L. Hosfield 1999. Flavonol glycosides from Montcalm dark red kidney bean: Implications for the genetics of seed coat color in Phaseolus vulgaris L. J. Agr. Food Chem. 47:4079-4082.

Beninger, C.W.. G.L. Hosfield, and M.J. Bassett. 1999. Flavonoid composition of three genotypes of dry bean (Phaseolus vulgaris L.) differing in seed coat color. J. Amer. Soc. Hort. Sci. 124:514-518.

Beninger, C.W., G.L. Hosfield, and M.G. Nair. 1998. Flavonol glycosides from a new Manteca-type dry bean (Phaseolus vulgaris L.). J. Agr. Food Chem. 46:2906-2910.

Dewick, P.M. 1994. Isoflavonoids, p. 117-232, In: J.B. Harborne (ed.). The flavonoids: Advances in research since 1986. Chapman and Hall, New York.

Dixon, R.E., E.R. Blyden, M.P. Robbins, A.J. Van Tunen, and J.N. Mol. 1988. Comparative biochemistry of chalcone isomerases. Phytochemistry 27:2801-2808.

Dooner, H., T.P. Robbins, and R.A. Jorgensen. 1991. Genetic and developmental control of anthocyanin biosynthesis. Annu. Rev. Genet. 25:173-199.

Feenstra, W.J. 1960. Biochemical aspects of seedcoat colour inheritance in Phaseolus vulgaris L. Meded. Landbouwhogeschool Wageningen 60-2:1-53.
Haley, S.D., L. Afanador, and J.D. Kelly. 1994. Identification and application of a random amplified polymorphic DNA marker for the $I$ gene (potyvirus resistance) in common bean. Phytopathology 84:157160.

Heller, W. and G. Forkman. 1994. Biosynthesis of flavonoids, p. 499_ 535. In: J.B. Harborne (ed.). The flavonoids: Advances in research since 1986. Chapman and Hall, New York.

Koes, R.E., F. Quattrocchio, and J.N.M. Mol. 1994. The flavonoid biosynthetic pathway in plants: function and evolution. Bioessays 16:123-132.

Kooiman, H.W. 1920. Over de erfelijkheid van de kleur der zaadhuid van Phaseolus vulgaris. Dissertation, Utrecht. Van Dishoeck, Bussum.

Kyle, M.M. and M.H. Dickson. 1988. Linkage of hypersensitivity to five viruses with the $B$ locus in Phaseolus vulgaris L. J. Hered. 79:308-311.

Lamb, C.J., M.A. Lawton, M. Dron, and R.A. Dixon. 1989. Signals and transduction mechanisms for activation of plant defenses against microbial attack. Cell 56:215-224.

Lamprecht, H. 1932. Beitrage zur Genetik von Phaseolus vulgaris zur Vererbung der Testa Farba. Hereditas 16:169-211.

Lamprecht, H. 1940. Zur Genetik von Phaseolus vulgaris XVII-XVIII. Zwei neue Gene fur Abzeichen auf der Testa "Punc" and "Mip" sowie die Virkung von "V" und "Inh." Hereditas 26:292-304.

Leakey, C.L.A. 1988. Genotypic and phenotypic markers in common bean, p. 245-327. In: P. Gepts (ed.). Genetic resources of Phaseolus beans. Kluwer Academic Publishers, Boston.

Mehdy, M.C. and C.J. Lamb. 1987. Chalcone isomerase cDNA cloning and mRNA induction by fungal elicitor, wounding and infection. Embo 6:1527-1533.

Park, S.J. and J.C. Tu. 1986. Association between BCMV resistant I gene and eye color of cv. Steuben. Annu. Rpt. Bean Improvement Coop. 29:4-5.

Pierce, W.H. 1934. Viruses of the bean. Phytopathology 24:87-115.

Prakken, R. 1970. Inheritance of colours in Phaseolus vulgaris L. II. A critical review. Med. Landbouwhogeschool Wageningen 70-23:1-38.

Prakken, R. 1972. Inheritance of colours in Phaseolus vulgaris L. III. On genes for red seedcoat colour and a general synthesis. Meded. Landbouwhogeschool Wageningen 72-29:1-82.

Rommeswinkel, M., B. Karwatzki, L. Beerhues, and R. Wiermann. 1992. Immunofluorescence localization of Pisum sativum L. and Phaseolus vulgaris L. and comparable immunochemical analysis of chalcone synthase from pea leaves. Protoplasma 166:115-121.

Sablowski, R.W.M., E. Moyano, F.A. Culianez-Macia, W. Scuch, C. Martin, and M. Bevan. 1994. A flower-specific Myb protein activates transcription of phenylpropanoid biosynthetic genes. Embo 13: 128137.

SAS Institute, Inc., 1989. SAS/STAT user's guide, version 6.0, 4th ed. Vol. 1. SAS Inst. Inc., Cary, N.C.

Takeoka, G.R., L.T. Dao, G.H. Full, R.Y. Wong, L.E. Harden, R.H. Edwards, and J.J. Berrios. 1997. Characterization of black bean (Phaseolus vulgaris) anthocyanins. J. Agr. Food Chem. 45:3395-3400.

Temple, S.R. and F.J. Morales. 1986. Linkage of dominant hypersensitive resistance to bean common mosaic virus to seed color in Phaseolus vulgaris L. Euphytica 35:331-333. 